\title{
Correspondência epistolar e as possibilidades do comércio português na Itália em 1800
}

\author{
José Jobson de Andrade Arruda \\ Departamento de História - FFLCH/USP
}

Os anos 80 , dos setecentos, marcam a inauguração de uma vigorosa ofensiva da diplomacia portuguesa objetivando ampliar o raio de ação do comércio português. Instrumento importante da consecução dessa política de expansão comercial foram as Instruções, Convenções e Tratados Comerciais. As Instruções, particularmente, revelam aspectos significativos dessa política, baixadas em 1781 e 1789 , respectivamente (1). Esta última orienta os Cônsules no sentido de promoverem o comércio português no exterior, motivo essencial da nomeação e existência mesma dos Cônsules, concitando-os a manterem uma correspondência sistemática com a Real Junta do Comércio, Agricultura, Fábricas e Navegação, a fim de que esta pudesse tomar as medidas adequadas à dinamização daquelas atividades.

E exatamente neste contexto que emerge a correspondência epistolar conservada na Academia de Ciências de Lisboa, sobrelevando, pela sua acuidade na precepção dos problemas atinentes ao trato mercantil, a Carta datada de 21 de abril de 1800, proveniente da cidade de Veneza (2), de autor anônimo. Trata do comércio português na Itália nos últimos anos do século XVIII, indicando suas vicissitudes e os meios para superá-las, apontando o caminho pelo qual se poderia ampliar o tráfico mercantil português nos portos italianos.

(1) - Colleç̧ão Official de Legislação Portuguesa Impressa e Manuscrita, coligida por Francisco Manuel Trigoso de Aragão Morato, vol. 23, doc. 139 e Colleção de Legislação Portuguesa, Antonio Delgado da Silva, pp. 566-570.

(2) - Carta de 21 de abril de 1800. Academia de Ciências de Lisboa, Ms. 1.700, doc. 1, f. 56. Este importante documento foi utilizado pela primeira vez por Fernando Antonio Novaes no capítulo IV, "A política Colonial”, de sua tese Portugal e Brasil na Crise do Antigo Sistema Colonial (1777-1808). São Paulo, Hucitec, 1979, a quem agradecemos a cessão do microfilme relativo ao documento. 
Em relação ao documento, propriamente dito, o primeiro problema, até o presente momento insolúvel, é o da autoria. Foi escrito em 21 de abril de 1800 , em Veneza, e enviado ao Regente D. João, efetivado no governo a partir de 1792, quando enloqueceu sua mãe a Rainha D. Maqia (3). $O$ redator da carta encontrava-se na Itália, ao que parece em missão oficial, pois o Regente lhe ordenava que mandasse notícias; sabe-se também que serviu em empregos públicos pelo prazo de sete anos, em várias repartições, e o salário que recebia não the parecia compensador pelo acúmulo de trabalho que a função lhe impunha (4). Parece qualificado para a redação de noticiário sobre a situação do comércio português na Itália, pois viajou pela Itália e Alemanha para recolher dados no período de cinco anos, a partir de 1795, sobre os quais trabalhou e meditou (5).

O texto é claro na sua distribuição. Inicia-se com uma apresentação do estado atual do comércio português na Itália, falando desse novo comércio como sinônimo de indústria, isto é, atividade produtiva, que envolve a aplicação de trabalho. Insiste na importância do comércio com a Itália pelo fato de obviar o caminho das mercadorias para a Suiça, Alemanha e Levante. Aponta uma circunstância de momento que favorece aos portugueses, a decadência das colônias francesas que abasteciam esses mercados (6), o que permitira aos portugueses atingirem até mesmo o mercado francês, aproveitando-se do vácuo criado por causa do regime violento na França (7).

Essas observações são absolutamente pertinentes e até mesmo visionárias. De fato, a convulsão social e política gerada pela Revolução Francesa desorganizou o sistema colonial francês na medida em que estimulou as insurreições coloniais (8) e alterou o equilíbrio político internacional, dan-

(3) - Serrão, Joel, Cronologia Geral da História de Portugal. Lisboa, Iniciativas Editoriais, 1971, p. 137.

(4) - Carta de 21 de abril, citada, f. 56.

(5) - Carta citada, f. 56.

(6) - Idem, f. $56 \mathrm{v}$.

(7) - Idem, f. 57.

(8) - As discussões em torno da igualdade das "gentes de cor livres" provocaram tumultos nas Antilhas. $O$ recrudescimento da crise fê-la alastrar-se dos livres aos escravos, e os plantadores pediram a intervenção inglesa a partir de 1793. Em San Domingos, um escravo liberto, Toussaint-Louverture, dominava praticamente a totalidade da ilha em 1799. Guadalupe e Santa Lúcia estavam em mãos dos franceses, mas Tobago e Martinica haviam passado aos ingleses. Convulsões semelhantes ocorreram no Senegal. Cf. Godechot, Jean, Las Revoluciones (1770-1799), (trad. espanhola Nueva Clio). Barcelona, Editora Labor, 1969, pp. 114-115. 
do origem às guerras do final do século XVIII (9), das quais se aproveitou a Inglaterra para assenhorear-se do comércio marítimo, principalmente colonial. A França sentiu profundamente o golpe, pois dependia dos produtos coloniais para manter o ritmo das suas exportaçōes e até mesmo o superavit da sua Balança de Comércio (10). As dificuldades francesas reverteram em benefício do comércio português com a França, que passava a depender dos produtos coloniais portugueses para manter o ritmo da sua industrialização. As exportações portuguesas para a França arrancam da quase imobilidade no ano de 1799 , para $38,8 \%$ em 1807 , tendo esse crescimento se iniciado precisamente em 1800, como vaticinara o esperto missivista (11).

Nesse intróito, uma segunda constatação importante é feita pelo autor da Carta, a de que as relações políticas no Mediterrâneo tendiam a apresentar uma nova configuração (12), após os tratados de aliança e comércio efetivados com uma potência italiana (13), o que permitiria uma ampliação da rede comercial portuguesa no Mediterrâneo e Adriático, ainda mais porque essa potência poderia contribuir na superação de obstáculos existentes para o comércio português noutra potência, sua confinante (14).

Segue-se uma exposição dos principais óbices à expansão do comércio português na Itália, divididos em obstáculos internos e externos.

(9) - As guerras entre a França e a Inglaterra, iniciadas em 1793, sofreram um breve interregno em 1802 quando da Paz de Amiens, para retomarem furiosamente - seu curso com as campanhas napoleônicas do Império. Cf. Fugier, André, La Revolution Française et l'Empire Napoléonien, tomo IV da Histoire des Relations Internationales, dirigido por Pierre Renouvin. Paris, Hachette, 1954, passim.

(10) - "O movimento entre a França e as colônias - particularmente em direção 'às ilhas e colônias francesas da América' e no 'comércio da India' —, as importações são nitidamente superiores às exportações: indício certo do fato de que a política comercial francesa contava de maneira decisiva com os produtos 'coloniais' para manter o superavit comercial". Cf. Romano, Ruggiero, "Documenti e prime considerazioni intorno alla 'Balance du Commerce' della Francia dal 1817 al 1880", In Studi in Onori di Armando Sapori. Milano, 1957, p. 1278.

(11) - Arruda, J. J. de A., O Brasil no Comércio Colonial (1976-1808). São Paulo, Editora Ática, 1980, tabela 49, p. 307. Os dados referem-se aos produtos brasileiros consumidos pela França.

(12) - Carta citada, f. 57.

(13) - O autor está-se referindo, certamente, à "Convenção entre os muito altos e poderosos senhores Dona Maria Rainha de Portugal, e Victor Amadeo Rei de Sardenha, pela qual se estabelece huma reciproca igualdade a respeito das successões entre os seus respectivos vassallos, assinada em Lisboa pelos plenipotenciarios de huma, e outra corte em 11 de setembro de 1787 e ratificada por ambas as Magestades". Coleção de Leis, Decretos e Alvarás, Museu Paulista, vol. III, f. 370.

(14) - A referência à potência "confinante" nos leva a concluir que se trata da República de Gênova. 
Dentre os entraves internos, destaca cinco problemas fundamentais. $O$ primeiro referia-se à estrutura da sociedade, particularmente à classe mercantil, que divide em duas categorias. A primeira classe, à qual era necessário impor uma nova orientação ao investimento dos seus capitais, era constituída pelos comerciantes que investiam o grosso de seus capitais na aquisição de monopólios e contratos, que resultavam em apropriação das rendas públicas e acúmulo de bens que se destinavam parcialmente ao comércio com a Ásia e as Colônias e a compra de terras cujos lucros líquidos não ultrapassavam a 1 ou 2 por cento (15). Disso resultavam danos ao erário público, à agricultura, à indústria e ao comércio interno e, por decorrência, à riqueza real da nação (16). A segunda classe, constituída pelos comerciantes que aplicavam o grosso do seu capital ao comércio com as Colônias, auferia lucros vultosos, dado o seu caráter exclusivo, pois não sofria a concorrência dos comerciantes estrangeiros. Tais lucros exigiam pouco trabalho e praticamente nenhuma inteligência e, de ordinário, os lucros auferidos nessas comissões eram orientados para a busca da honra, da ascensão social, na medida em que procuravam ingressar na órbita da primeira classe e, portanto, na sua forma específica de ação econômica (17).

O segundo obstáculo ao comércio português na Itália era a mentalidade dos empresários portugueses, excessivamente acostumados ao lucro fácil prodigalizado pelos monopólios e que, por isso mesmo, não tinham necessidade e nem desejavam arriscar seus capitais em empreendimentos menos garantidos. Disso resultava inércia, falta de criatividade, métodos rotineiros e inexistência de correspondência epistolar-mercantil, o que facilitava o trabalho dos concorrentes estrangeiros estabelecidos em Portugal, conhecedores do comercado e das táticas especulativas. Por isso mesmo, o - comércio bancário era praticamente desconhecido, não havendo sequer livros de comprovação semanal das taxas de câmbio, tão comuns nas principais praças européias (18).

O terceiro obstáculo resulta dos dois primeiros, a falta de crédito, sem o qual não se pode estabelecer um comércio intenso pela escassez de capital de giro. Tanto que na Itália só existiam três ou quatro casas de comerciantes portugueses, pois não bastava ser milionário para se estabelecer como comerciante; entrava em jogo o tipo de comércio, o conhecimento desta especialidade, a manutenção de uma correspondência atuali-

(15) - Carta citada, f. 58.

(16) - Idem, f. $58 \mathrm{v}$.

(17) - Idem.

(18) - Carta citada, f. 59. 
zada e escrupulosa (19). Em conseqüência dessa falta de crédito, as casas estrangeiras só faziam comércio de comissão, o que impedia um fluxo constante de cargas de torna-viagem para as embarcações portuguesas, exigindo o dobro do capital necessário para uma operação mercantil comum. Em época de guerras, expedição de esquadras, movimentação de tropas por terra, em suma, na realização de qualquer tipo de despesas mais consideráveis por parte do Estado no estrangeiro, este se via na obrigação de contrair crédito junto a três ou quatro casas comerciais mais poderosas (20), cujos lucros significam prejuizo para o Estado. Concedendo crédito consideram que fazem favor ao Estado, sendo, portanto, merecedoras de honras e distinções bem como garantia dos monopólios e contratos (21).

O quarto obstáculo indicado pelo autor anônimo era o alto preço dos fretes e dos seguros marítimos e a imperícia dos capitães portugueses na navegação através do Mediterrâneo. Os últimos navios portugueses chegados a Veneza pagaram 600 réis de frete por arroba de açúcar transportado (22) e $18 \%$ de seguro. Nessa medida, para manter o lucro em relação a tais despesas, seria necessário aumentar os preços proporcionalmente, o que não era possível, pois as refinarias que adquiriam o açúcar português, na Áustria e em Veneza, eram obrigadas a manter preços de concorrência compatíveis com os preços do açúcar refinado em Hamburgo. Ainda mais, como as casas refinadoras venezianas tinham sucursais em Lisboa, estavam muito bem informadas sobre o andamento dos estoques de açúcar, o que lhes permitia barganhar o preço (23).

O quinto obstáculo derivava do pequeno cuidado que os colonos da América tinham na produção dos seus gêneros de exportação (24). Urgia o aperfeiçoamento da produção para que se aumentasse a capacidade competitiva tanto em preço quanto em qualidade. Sendo tão férteis as terras da América, difícil seria acreditar que não pudessem produzir açúcares superiores aos de São Domingos e Havana, café melhor que os de Martinica e Levante, arroz mais fino do que o produzido nos Estados Venezianos. Porém, muito da inferioridade dos gêneros comercializados pelos portugueses advinha das péssimas condições de armazenamento, onde os produtos se deterioravam, deixados ao relento, sujeitos a furto, sem discricriminação das mercadorias pertencentes a comerciantes nacionais ou estran-

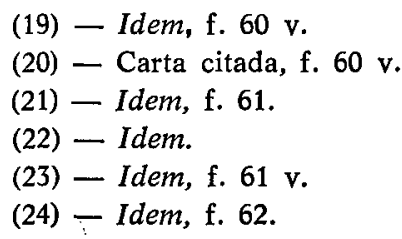


geiros, sem separação adequada dos gêneros para evitar contaminação (25). As alfândegas eram pequenas para permitir o adequado acondicionamento dos gêneros; a organização insuficiente exigia tempo e dinheiro para a localização das mercadorias e a sua retirada dos armazéns (26).

Os obstáculos externos à expansão do comércio português na Itália são divididos em três categorias. O primeiro era a intensa oposição que o comércio português sofria em todas as praças da Itália, especialmente porque, conhecedores do comércio português por terem casas instaladas em Portugal, de tudo faziam para impedir o êxito das iniciativas mercantis dos lusos, não havendo, portanto, nenhuma possibilidade de as casas comerciais portuguesas terem êxito se não fossem bem organizadas (27). O segundo era a falta de experiência dos comerciantes portugueses, quando comparados (28). E, finalmente, o terceiro, a guerra que no momento se desenvolvia contra Argel, o que prejudicava intensamente as relações comerciais no Mediterrâneo e no Adriático, a menos que se concluísse com eles um tratado de paz ou se organizasse uma esquadra para dar livre curso aos barcos mercantes de bandeira portuguesa (29).

Toda parte relativa ao encaminhamento de soluções para os problemas do comércio português na Itália é centrada numa solução de ordem burocrática, isto é, a criação do Agente de Comércio e do Comissário da Marinha, cujas funções se assemelharam largamente às funções dos cônsules. Percebendo que estava criando uma superposição administrativa, e, portanto, desnecessária, o autor da Carta procura demonstrar, primeiramente, que eles não são incompatíveis, possuindo cada um sua área definida de ação, cabendo ao Cônsul uma função mais geral e orientadora e ao Agente uma atribuição mais prática, mais próxima do trâmite mercantil. Ao final, entretanto, abandona gradativamente esta posição, indicando que os consulados vacantes poderiam ser preenchidos pelos Comissários da Marinha.

De tudo isso fica a impressão de que o Autor anônimo estava se propondo, indiretamente, para o exercício destas funções, ou de Agente de Comércio ou de Comissário da Marinha. Fica claro, entretanto, que os problemas apresentados pelo Autor não poderiam ser devidamente equacionados no nível exclusivo da burocracia, pela simples substituição do Cônsul pelo Agente. Os problemas presentes eram de natureza mais pro-
(25) - Carta citada, f. 62 v.
(26) - Idem, f. 63.
(27) - Idem, f. 63 v.
(28) - Carta citada, f. $64 \mathrm{v}$.
(29) - Idem, f. 67 v. 
funda. Contradições estruturais, assentadas na dinâmica do sistema mercantilista português, no qual a burguesia mercantil descansava sobre os pingues lucros da exploração colonial, descuidando do essencial investimento reprodutivo cujo processo de acumulação acabaria por transformar as forças produtivas. Exatamente o que se verificava nos centros econômicos mais dinâmicos, que cresceram na luta árdua contra o monopólio colonial de portugueses e espanhóis. No fundo, a estrutura da sociedade portuguesa permanecia largamente aristocrática e se ressentia de uma Revolução Burguesa que transformasse a própria natureza do Estado e da Sociedade. 